\title{
DNA and RNA polymerase activity in a Moniliophthora perniciosa mitochondrial plasmid and self-defense against oxidative stress
}

\author{
B.S. Andrade ${ }^{1,2}$, C. Villela-Dias ${ }^{3}$, D.S. Gomes ${ }^{3}$, F. Micheli ${ }^{3,4}$ and \\ A. Góes-Neto ${ }^{1}$ \\ ${ }^{1}$ Laboratório de Bioinformática, Departamento de Biologia, \\ Universidade Estadual do Sudoeste da Bahia, Jequié, BA, Brasil \\ ${ }^{2}$ Laboratório de Pesquisa em Microbiologia, \\ Departamento de Ciências Biológicas, \\ Universidade Estadual de Feira de Santana, Feira de Santana, BA, Brasil \\ ${ }^{3}$ Centro de Biotecnologia e Genética, Departamento de Ciências Biológicas, \\ Universidade Estadual de Santa Cruz, Ilhéus, BA, Brasil \\ ${ }^{4}$ CIRAD - Systèmes Biologiques (Bios) - Amélioration Génétique et Adaptation \\ des Plantes Méditerranéennes et Tropicales (UMR Agap), Montpellier, France
}

Corresponding author: B.S. Andrade

E-mail: bandrade@uesb.edu.br

Genet. Mol. Res. 12 (2): 1944-1950 (2013)

Received November 25, 2012

Accepted March 30, 2013

Published June 13, 2013

DOI http://dx.doi.org/10.4238/2013.June.13.3

ABSTRACT. Moniliophthora perniciosa (Stahel) Aime and PhillipsMora is a hemibiotrophic basidiomycete (Agaricales, Tricholomataceae) that causes witches' broom disease in cocoa (Theobroma cacao L.). This pathogen carries a stable integrated invertron-type linear plasmid in its mitochondrial genome that encodes viral-like DNA and RNA polymerases related to fungal senescence and longevity. After culturing the fungus and obtaining its various stages of development in triplicate, we carried out total RNA extraction and subsequent complementary DNA synthesis. To analyze DNA and RNA polymerase expression levels, we performed real-time reverse transcriptase polymerase chain reaction for various fungal phases of development. Our results showed that DNA and RNA polymerase gene 
expression in the primordium phase of M. perniciosa is related to a potential defense mechanism against $T$. cacao oxidative attack.

Key words: Moniliophthora perniciosa; Oxidative stress; Polymerases; Mitochondrial plasmid

\section{INTRODUCTION}

Moniliophthora perniciosa (Stahel) Aime and Phillips-Mora (2005) is a hemibiotrophic basidiomycete (Agaricales, Tricholomataceae) endemic to the Amazon basin and causes witches' broom disease in cocoa (Theobroma cacao L.). It is the only cocoa pathogen that grows along with the plant (Purdy and Schmidt, 1996; Aime and Phillips-Mora, 2005). This disease is one of the most important phytopathological problems in cacao-producing areas of the American continent and has decimated the Brazilian cacao industry during the last 2 decades (Griffith et al., 2003). After infection, the pathogen establishes a biotrophic relationship with its host; the monokaryotic mycelium progresses intercellularly in the plant tissues. Four to 6 weeks later, the hyphae become dikaryotic, develop clamp connections, and invade the cells (intracellular mycelium); this stage corresponds to the saprophyte phase of the fungus and ends with basidiocarp and basidiospore formation (Meinhardt et al., 2008).

In 2008, Formighieri et al. published the M. perniciosa mitochondrial genome and described the presence of a stable integrated invertron-type linear plasmid. This plasmid displays the characteristics of previously described linear mitochondrial plasmids (Kennell and Cohen, 2008) such as the presence of large terminal inverted repeats and 2 large open reading frames on opposite strands (Kempken, 1994). Moreover, the M. perniciosa linear-type plasmid encodes virallike DNA and RNA polymerases (Pöggeler and Kempken, 2004; Formighieri et al., 2008). Linear plasmids are commonly related to fungal senescence and longevity (Pöggeler and Kempken, 2004) owing to mitochondrial instability and plasmid insertions into the mitochondrial genome (Bertrand et al., 1985, 1986; Bertrand, 2000).

Based on the M. perniciosa mitochondrial genome sequence, the differential expression of mitochondrial genes - mainly associated with oxidative stress and glucose depletion - has been described for the biotrophic phase of the fungus in the plant (Scarpari et al., 2005; Rincones et al., 2008; Pires et al., 2009). In particular, Pires et al. (2009) provided the first description of the $M$. perniciosa primordium and basidiocarp development, dividing it into 6 stages according to mycelium color - white, yellow, pink, and dark pink - and developmental phase of the fructification body - primordium and basidiocarp. We used reverse transcriptase quantitative polymerase chain reaction (qPCR) to analyze the expression of DNA and RNA polymerase genes identified during fungal development (from the white mycelium phase to basidiocarp production). The relationship between DNA and RNA polymerase gene expression and the $M$. perniciosa potential defense mechanism against $T$. cacao oxidative attack during infection was also investigated.

\section{MATERIAL AND METHODS}

\section{M. perniciosa culture}

M. perniciosa (isolate 565 VA4 Comissão Executiva do Plano da Lavoura Cacauei- 
ra/Centro de Pesquisas do Cacau) was grown in an artificial system (cookies), as described by Niella et al. (1999). The fungus was inoculated in triplicate on plates containing potatodextrose-agar medium (20,2, and $2 \%$, respectively) and incubated at $25^{\circ} \mathrm{C}$ for $10-15$ days. Subsequently, mycelium discs were used to inoculate cookies containing $37 \%$ dry broom, $9.8 \%$ oat, $1.5 \%$ calcium sulfate, and $51.7 \%$ water to achieve a saturation point. The culture was maintained at $21-25^{\circ} \mathrm{C}$ under $100 \%$ humidity and a 12 -h light regimen until the mycelium covered the entire cookie (approximately 15 days). The cookies were hung in sterile pots under the same temperature, humidity, and light conditions. The cookies were watered 2 or 3 times per week using $20 \mathrm{~mL}$ autoclaved water. To induce basidiomata production, we withdrew water for 15-20 days (water stress). Six phases of fungal development on the cookies were studied: 1) white phase, corresponding to the initial stage of fungus culture; 2) yellow phase, at which the mycelium displayed the first change from white to yellow; 3) pink phase, in which the mycelium changed from yellow to pink (this phase also preceded water stress); 4) dark pink phase, which occurred soon after water stress; 5) primordium phase, at which primordia were formed; and 6) basidiomata phase, at which the fruiting bodies were fully developed. Two additional fungal development phases were used in the analysis: 1) primary mycelium (monokaryotic without clamp connections) and 2) secondary mycelium (dikaryotic with clamp connections). These phases were obtained by cultivating the mycelium starter cultures on potato-dextrose-agar medium for 3 weeks in darkness at room temperature. The mycelium was ground in liquid nitrogen and kept at $-80^{\circ} \mathrm{C}$ until use.

\section{RNA extraction and complementary DNA (cDNA) synthesis}

Total RNA extraction was performed from $500 \mathrm{mg}$ ground material by using an RNeasy Midi Kit (Qiagen, The Netherlands) according to manufacturer recommendations. Total RNA was treated with DNase I (Fermentas, Hanover, MD, USA) according to the manufacturer protocol and then separated on 1\% diethylpyrocarbonate-treated agarose gel and stained with ethidium bromide to confirm RNA integrity and estimate RNA concentration. The cDNA was synthesized using reverse transcriptase (RevertAid ${ }^{\mathrm{TM}} \mathrm{H}$ Minus M-MuLV, Fermentas) according to manufacturer recommendations. Briefly, the reaction mixture containing 10 $\mu \mathrm{g}$ total RNA, $2.5 \mathrm{mM}$ of each deoxyribonucleotide triphosphate, $20 \mathrm{U}$ RNase inhibitor, 0.5 $\mu \mathrm{g}$ oligo(dT), and $200 \mathrm{U}$ RevertAid ${ }^{\mathrm{TM}} \mathrm{H}$ Minus M-MuLV was incubated at $42^{\circ} \mathrm{C}$ for $1 \mathrm{~h}$. The reverse transcriptase was inactivated at $70^{\circ} \mathrm{C}$ for $10 \mathrm{~min}$.

\section{qPCR analysis}

qPCR analysis was carried out for the DNA and RNA polymerase genes with the actin gene of M. perniciosa as a reference (endogenous control; Table 1). Primers were designed using Integrated DNA Technologies Scitools Realtime PCR [http://www.idtdna.com/ Scitools/Applications/RealTimePCR/ (accessed November 25, 2012)]. Quantitative PCR was performed using SYBRGreen ${ }^{\circledR}$ (Invitrogen) for the detection of fluorescence during amplification, and assays were performed on an ABI PRISM 7500 Sequence Detection System coupled to the ABI PRISM 7500 SDS software (Applied Biosystems, Foster City, CA, USA) using standard settings. A $20-\mu \mathrm{L}$ reaction mixture containing $10 \mu \mathrm{L}$ single-stranded cDNA, $2 \mu \mathrm{L} 1 \mathrm{X}$ SYBRGreen $^{\circledR}$ (Invitrogen), 1X PCR buffer, $200 \mathrm{mM}$ deoxyribonucleotide triphosphate, $3 \mathrm{mM}$ 
$\mathrm{MgCl}_{2}, 1 / 250 \mathrm{X}$ Rox, and $200 \mathrm{nM}$ of each primer was used for qPCR. The thermal cycling conditions were as follows: $50^{\circ} \mathrm{C}$ for $2 \mathrm{~min} ; 94^{\circ} \mathrm{C}$ for $10 \mathrm{~min} ; 40$ cycles of $94^{\circ} \mathrm{C}$ for $45 \mathrm{~s}, 61^{\circ} \mathrm{C}$ for $35 \mathrm{~s}$, and $72^{\circ} \mathrm{C}$ for $35 \mathrm{~s}$. A dissociation analysis was conducted to check for the formation of primer dimers and hairpins. The melting temperatures of the fragments were determined according to manufacturer protocols. No template reactions were included as negative controls in every plate. The expression of each gene was determined through comparison to the expression level of the actin gene (relative quantification $/ 2^{\Delta \Delta C \mathrm{~T}}$ ). Automated gene expression analysis was performed using the Applied Biosystems 7500 System SDS software (v1.3.1.21).

\begin{tabular}{|c|c|c|c|}
\hline Gene & Primer sequence $\left(5^{\prime}-3^{\prime}\right)$ & $\operatorname{Tm}\left({ }^{\circ} \mathrm{C}\right)$ & Amplicon (bp) \\
\hline DPO & $\begin{array}{l}\text { F: CACTGGAGGTAGTGTGGATGTTTAC } \\
\text { R: TTGGTTCACCTGTTGGCATA }\end{array}$ & $\begin{array}{l}45 \\
45\end{array}$ & 70 \\
\hline RPO & $\begin{array}{l}\text { F: TTGAAAAAGAAAAGCAATACTCATTTGA } \\
\text { R: AGATGTTTCTTATTGTTTGATCCACC }\end{array}$ & $\begin{array}{l}47 \\
48\end{array}$ & 247 \\
\hline ACT1* & $\begin{array}{l}\text { F: CCCTTCTATCGTCGGTCGT } \\
\text { R: AGGATACCACGCTTGGATTG }\end{array}$ & $\begin{array}{l}81 \\
81\end{array}$ & 121 \\
\hline
\end{tabular}

$\mathrm{F}=$ forward primer; $\mathrm{R}=$ reverse primer. *Indicates transcript used for normalization (actin).

\section{RESULTS}

Analysis of DNA and RNA polymerase expression from the mitochondrial plasmid of $M$. perniciosa revealed that these genes are expressed in almost all phases of the life cycle of the fungus cultivated on cookies; in the dark pink phase, only DNA polymerase was expressed (Figure 1).

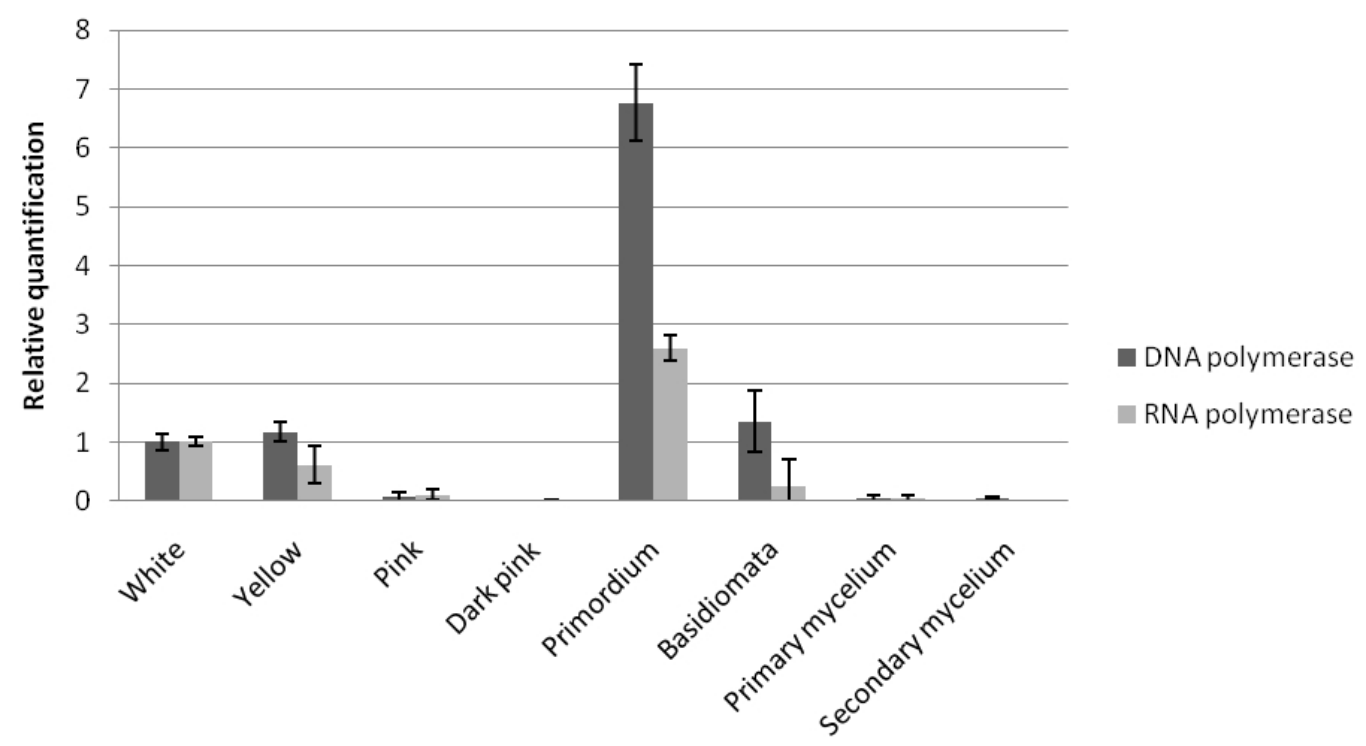

Figure 1. Reverse transcriptase quantitative polymerase chain reaction of DPO and RPO genes expressed in different phases during the culture of Moniliophthora perniciosa. 
Relative expression of the DNA and RNA polymerase genes was highest in the primordium phase - approximately 6.5 and 2.5 times higher, respectively, than that in the white phase (see Figure 1). In the dark pink phase, which occurs just before the primordium phase, curved hyphae leading to possible hyphal fusion and the formation of the primordia apex have been observed.

\section{DISCUSSION}

Although no prior information about the probable function of these enzymes in the metabolism of M. perniciosa is available (Formighieri et al., 2008), these molecules are implicated in the replication mechanism and expression of the mitochondrial genome (Kempken, 1994; Kennell and Cohen, 2005) through a degree of structural and sequence identity with other fungal plasmid polymerases (Andrade et al., 2009). Given this function, the activity of these enzymes may contribute to increasing the survival of the fungus, as described in the pAL2 plasmid of Podospora anserina (Hermanns et al., 1994; Maas et al., 2007). The LaBelle Neurospora crassa strain displayed a plasmid region that encodes a DNA polymerase close to the mitochondrial DNA ( $\mathrm{mtDNA}$ ) promoter, indicating that this polymerase is maintained throughout the process of evolution by selective pressure and may contribute functionally to mtDNA (Cahan and Kennell, 2005).

Primordial development results in primary hyphal nodules as well as internal local aggregations on dark, pinkish-red mycelia (Niella et al., 1999). Developmentally regulated genes related to the development of primordium and basidiomata have been identified for some basidiomycetes such as Agaricus bisporus (De Groot et al., 1997), Coprinopsis cinerea (Kues, 2000), and Pleurotus ostreatus (Lee et al., 2002), among others. In addition, the rapid increase in the availability of fully or partially sequenced genomes and expressed sequence tags from fungi in databanks has advanced the in silico identification of genes that may be involved in these processes (Nowrousian and Kück, 2006; Soanes and Talbot, 2006). Chitinase and ATG8 gene expression, which is likely involved in cell wall restructuration through autophagy in response to stress, has been observed in the primordium phase (Gomes DS, unpublished data).

Scarpari et al. (2005) published a biochemical study of T. cacao and M. perniciosa interaction that includes a systematic analysis of the changes in the content of soluble sugars, amino acids, alkaloids, ethylene, phenolics, tannins, flavonoids, pigments, malondialdehyde, glycerol, and fatty acids in cacao shoots during the development of the infected plant. Alterations in lipid metabolism during the infection were found to result in the highest glycerol content and lipid peroxidation through measurement of malondialdehyde. These metabolism alterations are common characteristics of senescence/programmed cell death in plants and are involved in the generation of reactive oxygen species (Blokhina et al., 2003). Reactive oxygen species production (Gratão et al., 2005) is related to lipid peroxidation (Rincones et al., 2008) and the degradation of calcium oxalate crystals (Ceita et al., 2007), which likely trigger mitochondrial recombination events and the formation of primordial fungi. The mainline effect of these events is likely a change in energy metabolism in the fungus, with increased expression (upregulation) of cytochrome p450 monooxygenase (Rincones et al., 2008). Thus, changes in the relative expression patterns of DNA and RNA polymerases in the mitochondrial genome of M. perniciosa likely influence the copying and transcription of several mitochondrial genes related to the process of plant-pathogen interaction and, in some ways, trigger self-defense metabolites produced by the fungus in T. cacao. 
The relative expression of DNA and RNA polymerases in the mitochondrial plasmid of M. perniciosa seems to follow the development of the fungus during its T. cacao infection. This study examined the expression of genes during various developmental phases of the fungus and demonstrated that the primordium phase displayed a clear difference in the expression of these polymerases compared with that at other phases. The relative increase of polymerase expression in the primordium phase matches the oxidative damage triggered in the plant, leading us to relate this process with a defense mechanism in the fungus when several substances produced by plant are degraded by the mitochondria of the fungus.

Although mitochondrial metabolism is highly dependent on the nuclear genome, the polymerases encoded by the plasmid integrated into the mitochondrial genome of M. perniciosa may function in metabolism. The DNA polymerase displayed expression that was relatively higher than that of RNA polymerase in the primordium phase and is probably related to the mechanism of mtDNA replication, preparing the fungus for basidiomata formation. It may also be involved in the repairing of mtDNA affected by oxidative stress triggered by the plant. Given its lower rate of expression compared to that of DNA polymerase, RNA polymerase likely plays a role in gene transcription in mitochondrial metabolism, increasing levels of cytochrome oxidase expression (upregulation) and thus helping to maintain energy metabolism and prepare the fungus for defense against $T$. cacao.

The results of this study may be useful for further elucidation of the mitochondrial metabolism of M. perniciosa and the development of new environmental controls of basidiomata initiation. In addition, this information may contribute to strategies to enhance the control of this phytopathogen and effectively monitor witches' broom disease in T. cacao.

\section{ACKNOWLEDGMENTS}

We thank Universidade Estadual de Feira de Santana and the graduate program in biotechnology at Universidade Estadual de Feira de Santana. We also thank Karina Gramacho (Centro de Pesquisas do Cacau) for donating the M. perniciosa strain used in this study.

\section{REFERENCES}

Aime MC and Phillips-Mora W (2005). The causal agents of witches' broom and frosty pod rot of cacao (chocolate, Theobroma cacao) form a new lineage of Marasmiaceae. Mycologia 97: 1012-1022.

Andrade BS, Taranto AG, Goes-Neto A and Duarte AA (2009). Comparative modeling of DNA and RNA polymerases from Moniliophthora perniciosa mitochondrial plasmid. Theor. Biol. Med. Model. 6: 22.

Bertrand H, Chan BS and Griffiths AJ (1985). Insertion of a foreign nucleotide sequence into mitochondrial DNA causes senescence in Neurospora intermedia. Cell 41: 877-884.

Bertrand H, Griffiths AJ, Court DA and Cheng CK (1986). An extrachromosomal plasmid is the etiological precursor of kalDNA insertion sequences in the mitochondrial chromosome of senescent neurospora. Cell 47: 829-837.

Bertrand H (2000). Role of mitochondrial dna in the senescence and hypovirulence of fungi and potential for plant disease control. Annu. Rev. Phytopathol. 38: 397-422.

Blokhina O, Virolainen E and Fagerstedt KV (2003). Antioxidants, oxidative damage and oxygen deprivation stress: a review. Ann. Bot. 91: 179-194.

Cahan P and Kennell JC (2005). Identification and distribution of sequences having similarity to mitochondrial plasmids in mitochondrial genomes of filamentous fungi. Mol. Genet. Genomics 273: 462-473.

Ceita GO, Macêdo JNA, Santos TB, Alemanno L, et al. (2007). Involvement of calcium oxalate degradation during programmed cell death in Theobroma cacao tissues triggered by the hemibiotrophic fungus Moniliophthora perniciosa. Plant Sci. 173: 106-117. 
De Groot PW, Schaap PJ, Van Griensven LJ and Visser J (1997). Isolation of developmentally regulated genes from the edible mushroom Agaricus bisporus. Microbiology 143 (Pt 6): 1993-2001.

Formighieri EF, Tiburcio RA, Armas ED, Medrano FJ, et al. (2008). The mitochondrial genome of the phytopathogenic basidiomycete Moniliophthora perniciosa is $109 \mathrm{~kb}$ in size and contains a stable integrated plasmid. Mycol. Res. 112: 1136-1152.

Gratão PL, Polle A, Lea PJ and Azevedo RA (2005). Making the life of heavy metal-stressed plants a little easier. Func. Plant Biol. 32: 481-494.

Griffith GW, Nicholson J, Nenninger A, Birch RN, et al. (2003). Witches' brooms and frosty pods: two major pathogens of cacao. New Zealand J. Bot. 41: 423-435.

Hermanns J, Asseburg A and Osiewacz HD (1994). Evidence for a life span-prolonging effect of a linear plasmid in a longevity mutant of Podospora anserina. Mol. Gen. Genet. 243: 297-307.

Kempken F (1994). Unique features of a linear plasmid of Ascobolous immerses: Implications for plasmid evolution in fungi. Curr. Top. Mol. Genet. 2: 207-218.

Kennel JC and Cohen SM (2005). Fungal Mitochondria: Genomes, Genetic Elements, and Gene Expression. In: The Handbook of Fungal Biotechnology (Arora DK, ed.). 2nd edn. Marcel Dekker Inc., New York, 131-143.

Kues U (2000). Life history and developmental processes in the basidiomycete Coprinus cinereus. Microbiol. Mol. Biol. Rev. 64: 316-353.

Lee SH, Kim BG, Kim KJ, Lee JS, et al. (2002). Comparative analysis of sequences expressed during the liquid-cultured mycelia and fruit body stages of Pleurotus ostreatus. Fungal Genet. Biol. 35: 115-134.

Maas MF, Sellem CH, Hoekstra RF, Debets AJ, et al. (2007). Integration of a pAL2-1 homologous mitochondrial plasmid associated with life span extension in Podospora anserina. Fungal Genet. Biol. 44: 659-671.

Meinhardt LW, Rincones J, Bailey BA, Aime MC, et al. (2008). Moniliophthora perniciosa, the causal agent of witches' broom disease of cacao: what's new from this old foe? Mol. Plant Pathol. 9: 577-588.

Niella GR, Resende ML, Castro HA, Silva LHCP, et al. (1999). Aperfeiçoamento da metodologia de produção artificial de basidiocarpos de Crinipellis perniciosa. Fitopatol. Bras. 24: 523-527.

Nowrousian M and Kück U (2006). Comparative gene expression analysis of fruiting body development in two filamentous fungi. FEMS Microbiol. Lett. 257: 328-335.

Pires AB, Gramacho KP, Silva DC, Goes-Neto A, et al. (2009). Early development of Moniliophthora perniciosa basidiomata and developmentally regulated genes. BMC Microbiol. 9: 158.

Pöggeler S and Kempken F (2004). Mobile Genetic Elements in Mycelial Fungi. In: THE MYCOTA II, Genetics and Biotechnology (Kück U, ed.). 2nd edn. Springer Verlag, Heidelberg, New York, Tokyo, 165-198.

Purdy LH and Schmidt RA (1996). Status of cacao witches' broom: biology, epidemiology, and management. Annu. Rev. Phytopathol. 34: 573-594.

Rincones J, Scarpari LM, Carazzolle MF, Mondego JM, et al. (2008). Differential gene expression between the biotrophiclike and saprotrophic mycelia of the witches' broom pathogen Moniliophthora perniciosa. Mol. Plant Microbe Interact. 21: 891-908.

Scarpari LM, Meinhardt LW, Mazzafera P, Pomella AW, et al. (2005). Biochemical changes during the development of witches' broom: the most important disease of cocoa in Brazil caused by Crinipellis perniciosa. J. Exp. Bot. 56: 865-877.

Soanes DM and Talbot NJ (2006). Comparative genomic analysis of phytopathogenic fungi using expressed sequence tag (EST) collections. Mol. Plant Pathol. 7: 61-70. 